\title{
Surface display of hirame novirhabdovirus (HIRRV) G protein in Lactococcus lactis and its immune protection in flounder (Paralichthys olivaceus)
}

\author{
Lining Zhao ${ }^{1}$, Xiaoqian Tang ${ }^{1,2^{*}} \mathbb{0}$, Xiuzhen Sheng ${ }^{1}$, Jing Xing ${ }^{1,2}$ and Wenbin Zhan ${ }^{1,2}$
}

\begin{abstract}
Background: Hirame novirhabdovirus (HIRRV) can infect a wide range of marine and freshwater fish, causing huge economic losses to aquaculture industry. Vaccine development, especially oral vaccine, has become an effective and convenient way to control aquatic infectious diseases. HIRRV glycoprotein $(\mathrm{G})$, an immunogenic viral protein is a potential vaccine candidate for prevention of the disease. Here, we aimed to construct a recombinant Lactococcus lactis strain expressing HIRRV-G on the cell surface as an oral vaccine to prevent HIRRV.
\end{abstract}

Results: Glycoprotein gene of HIRRV was successfully cloned and expressed in L. lactis NZ9000 in a surface-displayed form, yielding Ll:pSLC-G. An approximately $81 \mathrm{kDa}$ recombinant G protein (containing LysM anchoring motif) was confirmed by SDS-PAGE, western blotting and mass spectrometry analysis. The surface-displayed G protein was also verified by immunofluorescence and flow cytometry assays. Furthermore, to evaluate the potential of Ll:pSLC-G as oral vaccine candidate, flounders were continuously fed with commercial diet pellets coated with $1.0 \times 10^{9} \mathrm{cfu} / \mathrm{g}$ of induced LI:pSLC-G for 1 week. Four weeks later, booster vaccination was performed with the same procedure. Compared with the controls, LI:pSLC-G elicited significantly higher levels of specific IgM against HIRRV in flounder gut mucus at the second week and in serum at the fourth week $(p<0.05)$. Meanwhile, oral immunization with LI:pSLC-G could provide $60.7 \%$ protection against HIRRV infection and a significantly lower virus load was detected than the controls on the third day post-challenge $(p<0.01)$. Moreover, on the first day post 1-week feeding, approximately $10^{4}-10^{5}$ recombinant $L$. lactis cells were detected in every gram of foregut, midgut and hindgut of flounder, which were mainly localized at the bottom of gut mucus layer; and on day $21,10^{2}-10^{3} \mathrm{~L}$. lactis cells could still be recovered.

Conclusions: HIRRV-G protein was successfully expressed on the surface of L. lactis cells, which could trigger mucosal and humoral immune response of flounder and provide considerable immune protection against HIRRV. It suggests that genetically engineered L. lactis expressing G protein can be employed as a promising oral vaccine against HIRRV infection.

Keywords: Lactococcus lactis, HIRRV glycoprotein, Surface display, Oral vaccine, Immune protection, Flounder

\footnotetext{
*Correspondence: tangxq@ouc.edu.cn

${ }^{1}$ Laboratory of Pathology and Immunology of Aquatic Animals, KLMME,

Ocean University of China, 5 Yushan Road, Qingdao 266003, China

Full list of author information is available at the end of the article
} 


\section{Background}

Hirame novirhabdovirus (HIRRV), belonging to the genus Novirhabdovirus of Rhabdoviridae family, was first isolated from cultured flounder (Paralichthys olivaceus) and ayu (Plecoglossus altivelis) in Japan in 1984 [1]. Since then, it has been reported to infect several species of marine fish such as stone flounder (Kareius bicoloratus) [2], black seabream (Acanthopagrus schlegeli) [3] and spotted sea bass (Lateolabrax maculatus) [4], as well as two freshwater hosts, grayling (Thymallus thymallus) and brown trout (Salmo trutta) [5]. With significant morbidity and heavy economic losses, HIRRV has become a vital menace for aquaculture especially in Asia and Europe. Vaccination has become a rather important part of aquaculture, since it is considered one of the most effective disease control strategies [6]. With regard to rhabdovirus, viral glycoprotein is a spike protein responsible for virus attachment to cell receptors, and also determines the serological properties of rhabdovirus [7, 8]. So far, several vaccines against HIRRV, including subunit vaccine [9] and DNA vaccine [10, 11], were all developed based on the viral glycoprotein, which could induce a good protective immunity against HIRRV infection. Moreover, the recombinant viral hemorrhagic septicemia virus (VHSV) harboring HIRRV-G gene instead of VHSV-G gene could produce high serum neutralization titer against HIRRV but not VHSV in flounder [12]. These researches suggested that the glycoprotein of HIRRV was an attractive and promising vaccine candidate.

Oral vaccination has the advantages of being painless, less expensive and convenient to administration [13], which is particularly important and needed for aquatic animals, especially for fish fries. Oral vaccine can trigger both mucosal and systemic immune responses, which may enhance vaccine efficacy and minimize vaccine side effects by avoiding direct contact to the systemic circulation $[14,15]$. Lactic acid bacteria (LAB), most of which are generally regarded as safe (GRAS), have long been used in food fermentation and preservation [16]. For nearly three decades, they have been studied as live vehicles for the delivery of antigens to mucosal sites in human, mice and chickens [17-20]. In the recent years, several LAB live vector vaccines were developed against pathogens in aquatic animals, such as infectious pancreatic necrosis virus (IPNV) in rainbow trout [21], Streptococcus iniae and Edwardsiella tarda in flounder [22, 23] and Aeromonas veronii in common carp [24], and showed significant immune protective effects. Therefore, it will be a promising prospect to apply lactococcal expression systems for disease prevention and control in aquaculture.

In this study, we first designed an expression cassette in L. lactis NZ9000 using pNZ8148 vector, and with
HIRRV-G gene insertion, a recombinant $L$. lactis strain expressing $\mathrm{G}$ protein was constructed. After oral immunization, specific antibody responses in serum and gut mucus were analyzed in flounder model. Furthermore, the immune protective efficacies including virus load and relative percent survival (RPS) were investigated after HIRRV injection. In addition, we explored the survival and adhesion of the recombinant $L$. lactis in flounder intestine.

\section{Results}

Design and construction of expression cassette in L. lactis The signal peptide of Usp45 ( $\left.\mathrm{SP}_{\mathrm{Usp} 45}\right)$ and the $\mathrm{C}$ terminus of AcmA (cA, containing three LysM motifs), as integral components for the protein secretion and surface exposure, were cloned into pNZ8148 vector, yielding pSLC. And, multiple cloning site (MCS) sequence was artificially integrated behind the cA domain, providing a pathway for insertion of the target genes. In this way, HIRRV-G gene was successfully inserted, generating pSLC-G. Under the control of PnisA, the open reading frame (ORF) of the constructed expression cassette was 798 bp (pSLC, Fig. 1a) or 2250 bp (pSLC-G, Fig. 1b), which was confirmed by PCR and nucleotide sequencing.

After electrotransformation, the recombinant $L$. lactis NZ9000, named Ll:pSLC and Ll:pSLC-G, were induced by nisin and then subjected to SDS-PAGE and western blotting analysis. SDS-PAGE analysis exhibited enhancement of protein bands in bacterial cell lysate samples with molecular weights of approximately $28 \mathrm{kDa}$ (Ll:pSLC; Fig. 1c, lane 2) and $81 \mathrm{kDa}$ (Fig. 1c, lane 3) compared to the sample before induction of Ll:pSLC-G (Fig. 1c, lane 1 ), which was consistent with the expectations. Nevertheless, no corresponding protein bands appeared in all supernatant samples (Fig. 1c, lanes 4-6). The $81 \mathrm{kDa}$ protein band in lane 3 was submitted for mass spectrometry (MS) analysis, and the result showed that it matched 8 peptides in G protein of HIRRV with $15.4 \%$ coverage of amino acid sequences (Additional file 1: Figure S1).

\section{Characteristics of recombinant L. lactis expressing G protein}

HIRRV-G protein was expressed in E. coli Transetta with pET-28a system and mouse anti-rG polyclonal antibodies (Pab) was prepared. The results of western blotting showed that the anti-rG Pab could specifically recognize the recombinant $G$ protein expressed by $L$. lactis (Fig. 1c, lane 9), while no stained bands appeared in the cell lysate samples of non-induced L. lactis and induced Ll:pSLC (Fig. 1c, lanes 7 and 8). Meanwhile, the immunofluorescence assay (IFA) was further preformed to detect whether the HIRRV-G protein could display on the bacterial cell surface, and the result 

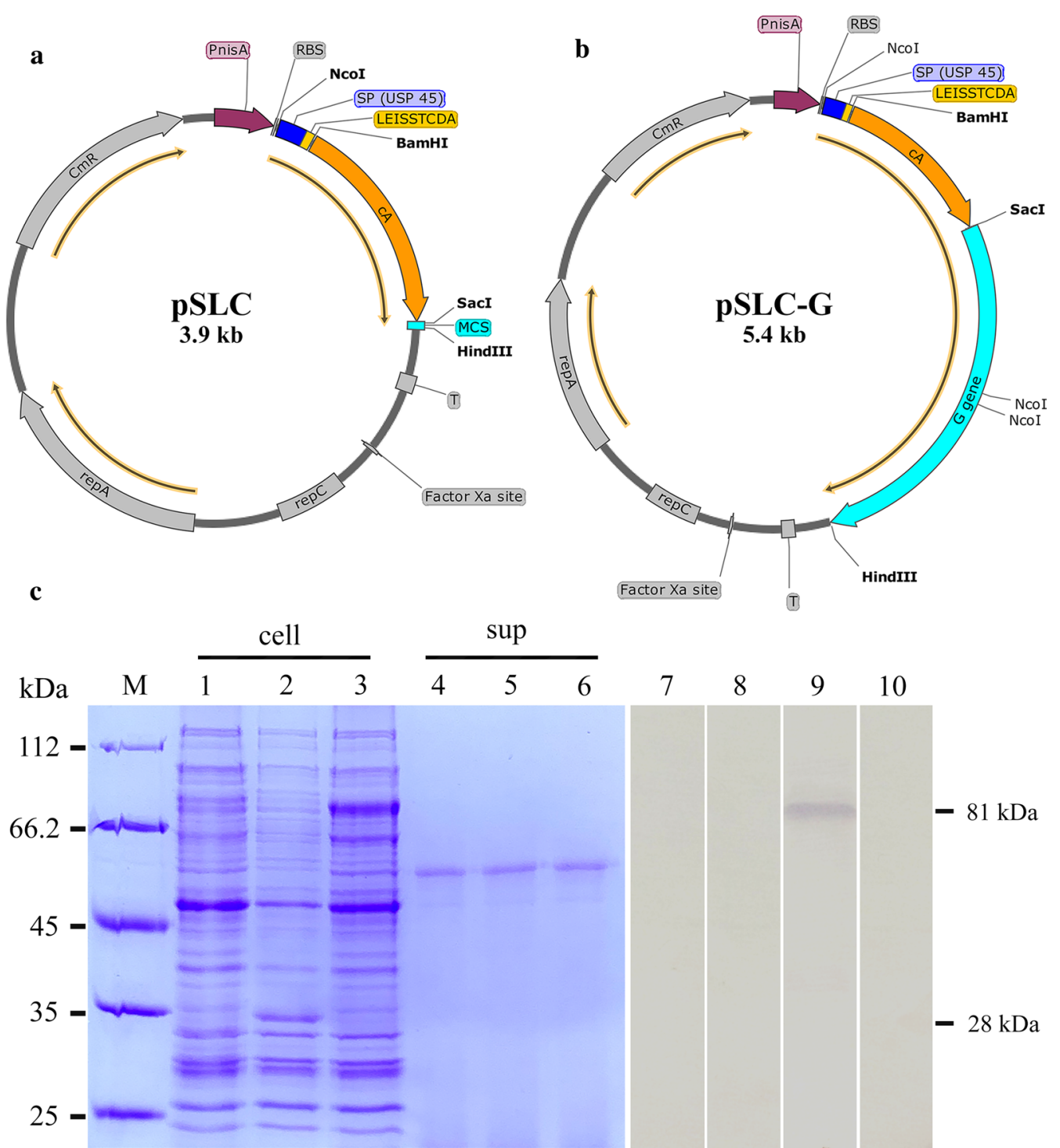

Fig. 1 Expression of G protein on L. lactis NZ9000. a, b Plasmid maps of constructed expression vector (by SnapGene software), arrows indicate the length and direction of the ORFs. a pSLC vector, an expression cassette with MCS; b pSLC-G vector, expressing HIRRV-G gene. c SDS-PAGE and western blotting analysis of the induced recombinant L. lactis. M: molecular mass marker; Lane 1-3: the whole cells lysate (cell) of non-induced L. lactis, induced LI:pSLC, induced LI:pSLC-G, respectively; Lane 4-6: the corresponding culture supernatants (sup); Lane 7-9: the corresponding western blotting of non-induced L. lactis, induced LI:pSLC and induced LI:pSLC-G incubated with mouse anti-rG Pab, respectively; Line 10: western blotting of induced LI:pSLC-G incubated with mouse negative serum

showed that specific green fluorescence was observed on the surface of Ll:pSLC-G after induction (Fig. 2a). Moreover, the flow cytometry (FCM) analysis showed that the proportion of positive bacteria was more than $85 \%$ after induction for $3 \mathrm{~h}$ (Fig. 2f). Based on these results, we can conclude that the HIRRV-G protein was successfully expressed and displayed on the cell surface of the L. lactis NZ9000.

\section{Colonization ability of recombinant $L$. lactis}

In order to detect the colonization of recombinant $L$. lactis in flounder intestine, the homogenates of foregut, midgut and hindgut were separately cultured on agar plates for 1-2 days. Typical colony characteristics, such as round, globular, white, with a smooth surface and entire edge, could be observed on the plates from the Ll:pSLC-G group, while no colonies were grown on plates 

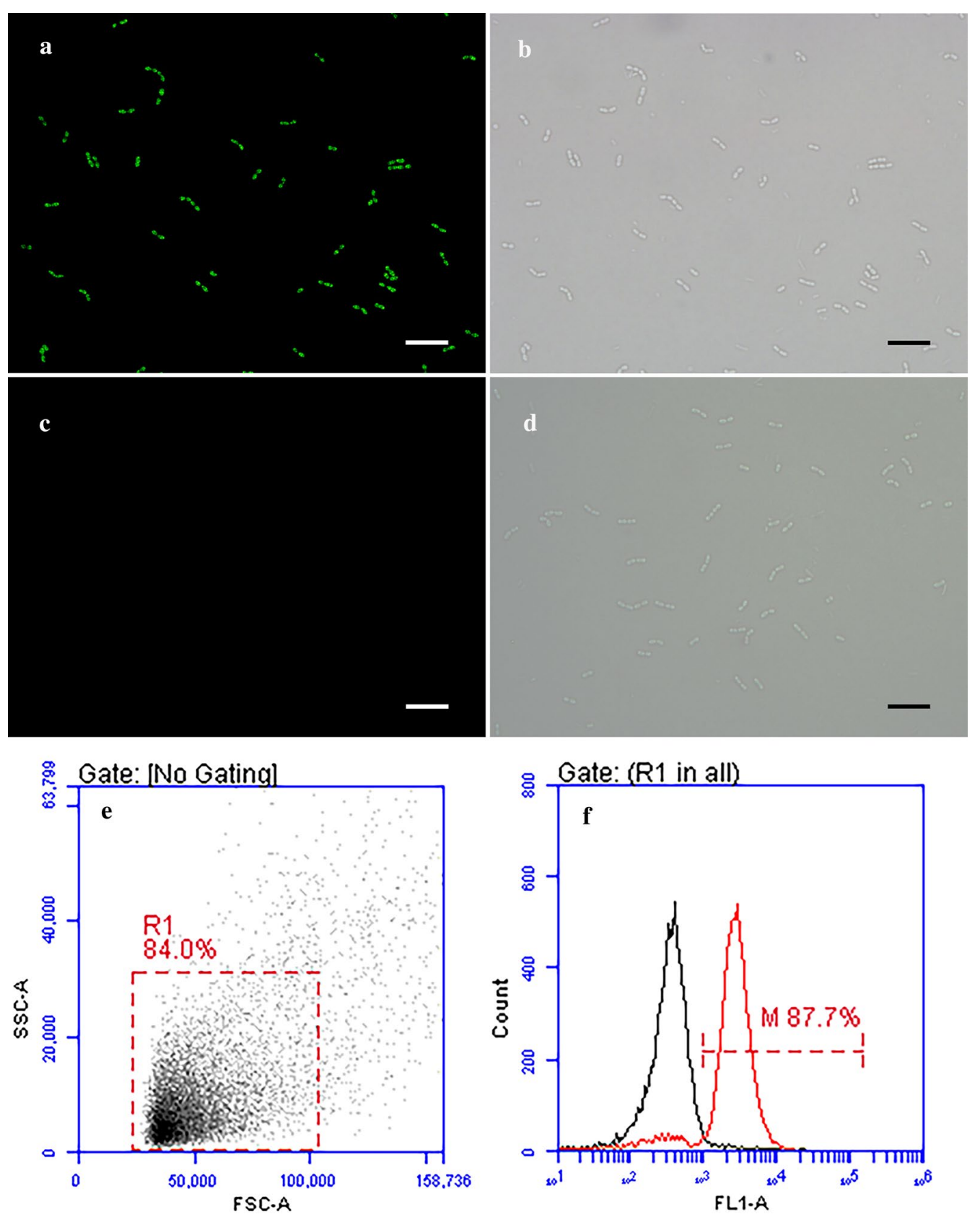

Fig. 2 The immunofluorescence microscopy and flow cytometry analysis of recombinant LI:pSLC-G after induction for 3 h. a, c Immunofluorescence-stained LI:pSLC-G with mouse anti-rG Pab (a) and mouse negative serum (c); $\mathbf{b}, \mathbf{d}$ bacteria were observed by interferential equipment in the same field as shown in a and $\mathbf{c}$. (Bars $=10 \mu \mathrm{m}$ ). e L. lactis NZ9000 gated (R1) on a FSC/SSC dot plots; f fluorescence histogram of gated bacteria showing the percentages of recombinant L. lactis expressed $\mathrm{G}$ protein

from PBS (phosphate buffered saline) group. The result of colony PCR confirmed that the cultured colonies were $L$. lactis NZ9000 harboring the pSLC-G.

Based on plate counts, we calculated the number of recombinant $L$. lactis attached to different regions of the intestinal mucosa of flounder (Fig. 3). On the first day after oral feeding for 1 week, the calculated number of cells was approximately $10^{4}-10^{5} \mathrm{cfu}$ per gram homogenate of flounder intestine. Adhesion was most prominent in midgut and the number of cells was up to $1.8 \times 10^{5}$ cfu per gram tissue. Then, the viable L. lactis gradually decreased with time. By the 14 th day, $10^{3}-10^{4}$ cfu per 


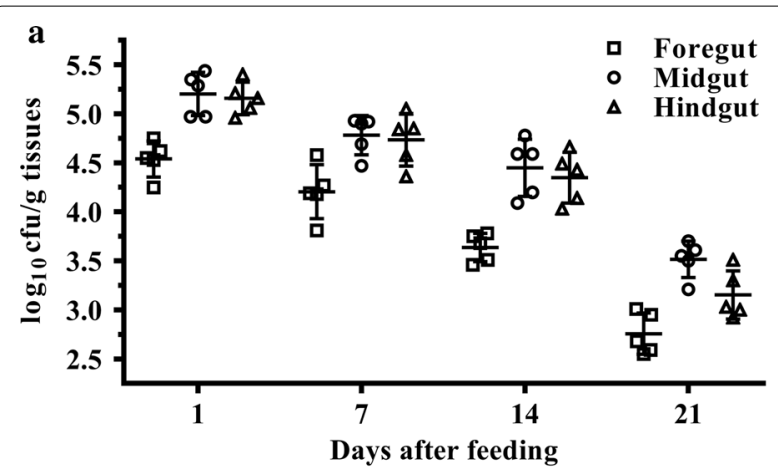

b

\begin{tabular}{|c|c|c|c|}
\hline $\begin{array}{l}\text { Percentage of remaining amount of } \\
\text { bacteria to the amount on day 1 (\%) }\end{array}$ & Foregut & Midgut & Hindgut \\
\hline 7 & 50.65 & 37.27 & 40.98 \\
\hline 14 & 12.19 & 18.84 & 16.71 \\
\hline 21 & 1.69 & 1.99 & 1.06 \\
\hline
\end{tabular}

Fig. 3 Survival and colonization of LI:pSLC-G in the intestine of flounder. a Viable count of L. lactis isolated from different sections of flounder intestine at days 1, 7, 14 and 21 after feeding $(n=5)$. Mean bacterium numbers and standard deviation were represented in $\log _{10}$ scale. b Percentage of remaining cells on days 7, 14 and 21 compared to that on day 1

gram tissue could still be recovered from foregut, midgut and hindgut, accounting for $12.2 \%, 18.8 \%$ and $16.7 \%$ of the cell number on the first day, respectively. On day 21 , the amount of $L$. lactis that remained adhered to the intestine tract was $10^{2}-10^{3} \mathrm{cfu}$, which is less than $2 \%$ of the cell number on the first day.

Double immunofluorescence staining was used to detect the recombinant $G$ protein on the cell surface of L. lactis NZ9000 located in flounder intestine. The results showed that L. lactis-positive red signals were mainly localized at the bottom of gut mucus layer, near the intestinal epithelial cell layer, and some in epithelial cell layer (Fig. 4c). According to the merged picture, most of the red signals could be co-localized with $\mathrm{G}$ protein-positive green signals (Fig. 4a), indicating that quite a large proportion of $L$. lactis could displayed G protein. No positive signals were observed in negative control staining.

\section{Antibody response against HIRRV in flounder}

The levels of specific anti-HIRRV IgM in serum and gut mucus of the immunized flounder were determined by ELISA (Fig. 5). It showed the similar dynamic trends in serum and gut mucus samples. Compared with the controls, significantly higher level of specific IgM was elicited in Ll:pSLC-G group $(p<0.05)$. And after booster immunization, higher levels of antibodies were also observed in the flounder vaccinated with Ll:pSLC-G. By contrast, there was no significant difference among the three control groups, where flounders were fed with commercial diet pellets coated with Ll:pSLC, L. lactis NZ9000 (Ll) or PBS, respectively. Besides, in Ll:pSLC-G group, significant high levels of IgM were detected in gut mucus rather than serum at week 2 , indicating that antibodies were elicited earlier in gut mucus.

\section{Immune protective efficacies against HIRRV}

The virus copies in spleens of challenged flounders on day 1 and 3 post-challenge were examined by qPCR, and the results were shown in Fig. 6a. In all experimental groups, the virus copies increased on day 3 compared to day 1. Compared with the controls, the fish in Ll:pSLC-G group had a significantly lower viral load on the 1st day post-challenge $(p<0.05)$, and extremely significant difference was detected on the 3rd day $(p<0.01)$. There was no statistical significant difference in virus copies among the three control groups $(p>0.05)$, but relatively low mean number of viral copies were detected in fish vaccinated with L. lactis NZ9000 and Ll:pSLC on the 3rd day.

The cumulative mortality of vaccinated fish after challenging with HIRRV were monitored (Fig. 6b). In PBS group, the fish began to die on 4th day post-challenge, and died quickly on 5th to 8th day; the cumulative mortality tended to be stable on day 10 at $93.3 \%$. As for two negative groups, group Ll and Ll:pSLC, the death both occurred on day 4 to day 11 , and the cumulative mortalities were $76.7 \%$ and $73.3 \%$, respectively. In contrast, the fish vaccinated with Ll:pSLC-G showed a significantly lower mortality of $36.7 \%$ compared with the controls. The RPS of the groups Ll:pSLC-G, Ll:pSLC and Ll were 60.7\%, $21.4 \%$ and $17.9 \%$, respectively. The infected fish exhibited typical signs of HIRRV infection, such as focal hemorrhage of the skeletal muscle and fins.

\section{Discussion}

With the extensive researches and long-term application, LAB have been proposed as mucosal delivery vehicles because of its safety and the capacity to survive in digestive tract. Due to the known complete genome, mature genetic tools and easiest genetic manipulability, L. lactis has been widely used for the development of candidate vaccines [25]. Till now, many different heterologous antigens have been efficiently produced in L. lactis [18, 2628]. Among them, the nisin-controlled gene expression (NICE) system remains one of the most promising and widely-used inducible systems based on nis A promoter, whose activity depends on extracellular concentration of nisin, a small peptide produced and secreted by several strains of L. lactis [29]. After genetic recombination, we constructed two recombinant plasmids, pSLC and pSLC$G$, which were then successfully transformed into $L$. lactis NZ9000 and induced by adding nisin. The expressed 

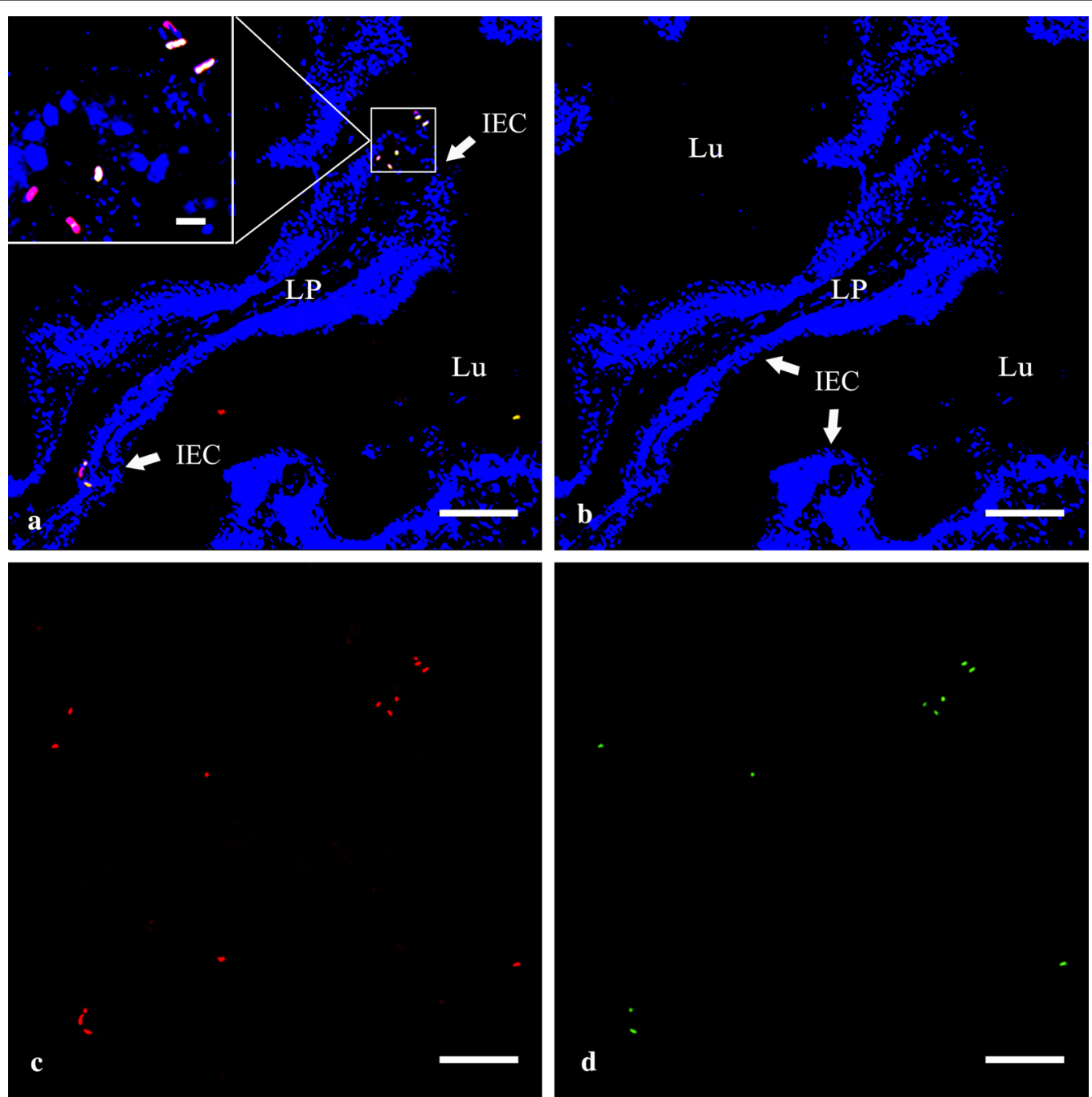

Fig. 4 Co-staining of L. lactis NZ9000 and recombinant G protein in flounder intestine on 3rd day after feeding. a The merged picture of $\mathbf{b}-\mathbf{d}$ $(\mathrm{bar}=50 \mu \mathrm{m})$; the corresponding enlarged drawing was shown in the upper left of the picture, $b a r=5 \mu \mathrm{m}$. $\mathbf{b}$ Cell nucleus were stained in blue by DAPI. c L. lactis NZ9000 was stained in red. d The expressed G protein was stained in green. LP lamina propria, Lu lumen; IEC intestinal epithelial cells

proteins could be clearly detected in SDS-PAGE and Western blotting, and the recombinant HIRRV-G protein was confirmed by MS, which indicated that the engineered G gene of HIRRV was accurately transcribed and translated into the target protein in this L. lactis expression system.

It is noticed that the locations of heterologous proteins produced in L. lactis can be intracellular, extracellular, and cell wall anchored. Displaying proteins on bacterial cell wall allows higher expression levels of protein and a better antigen exposure to the immune system [16]. Some studies demonstrated that surfacedisplayed strains could elicit a better immune response $[30,31]$. Therefore, we chose to construct a surface display system of $L$. lactis for vaccine development. To date, the signal peptide of Usp45 (an unknown secreted protein of $45 \mathrm{kDa}$ in L. lactis) is still the most generally used signal peptide in various expression system [16]. An interesting and valuable strategy is that synthetic LEISSTCDA peptide closely following the $\mathrm{SP}_{\mathrm{Usp} 45}$ may improve the secretion efficiency in L. lactis [32]. The cA domain of the AcmA is a very useful scaffold that can achieve cell surface display of heterologous proteins on various LABs [33]. Based on these expression elements, many proteins have been successfully expressed on the cell surface of bacteria [34-36]. In this work, according to the results of IFA and FCM analysis, the majority of cells were found to express HIRRV-G protein on the cell surface of recombinant $L$. lactis after induction. Thus, we can draw a conclusion that the HIRRV-G 


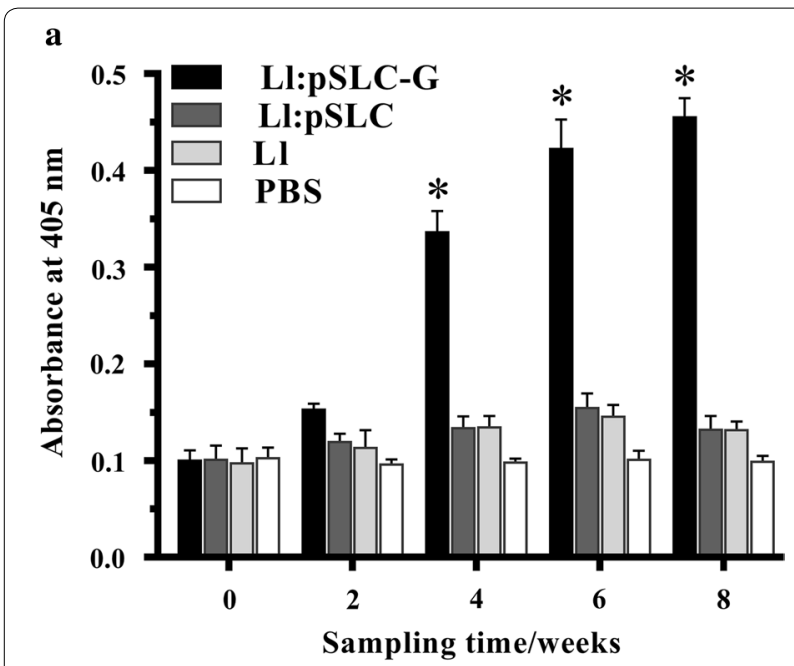

b

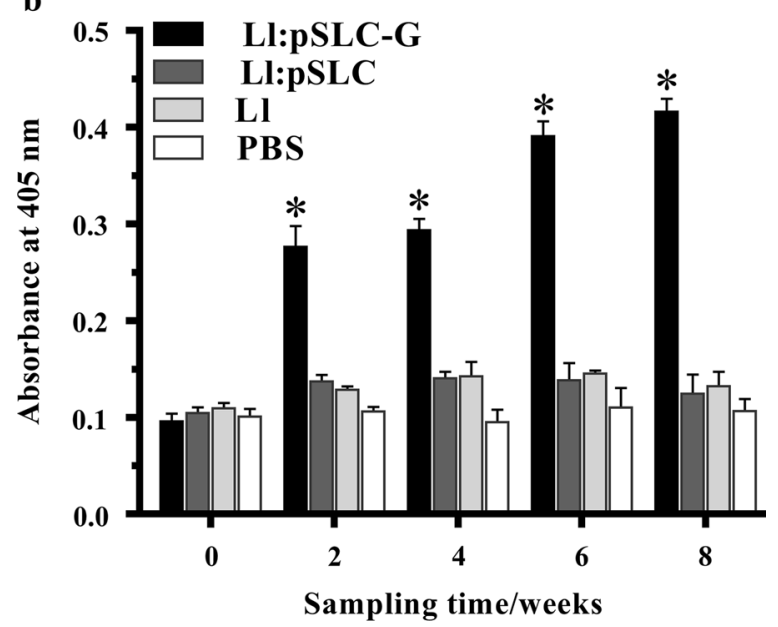

Fig. 5 Specific IgM against HIRRV in the serum (a) and gut mucus (b) in vaccinated flounder. Results are represented as mean \pm SD of five fish. Asterisks $\left(^{*}\right)$ on the bar represent the statistically significant difference $(p<0.05)$ as compared to PBS control

protein is successfully displayed on the surface of $L$. lactis, which laid the foundation for further application and effect evaluation of oral vaccine.

Rhabdoviruses consist of a helically wound ribonucleocapsid surrounded by a lipid bilayer, where glycoprotein projects outside in the form of non-covalently-bound [37]. As a spike protein, viral $G$ protein is considered to be a crucial antigenic determinant in rhabdovirus and almost the only protein that elicits neutralization antibody, which has been sufficiently proved in infectious hematopoietic necrosis virus (IHNV) [38], another virus in the same genus. In previous studies, HIRRV-G based subunit vaccine could bring out considerable protective effects against HIRRV injection [9], and DNA vaccine constructed based on HIRRV-G gene even showed a relatively higher protection level [10]. In this work, the live vector vaccine of recombinant $L$. lactis expressing $G$ protein exhibited a good protection of $60.7 \%$ against HIRRV infection, which is slightly lower than the effects of subunit and DNA vaccine. The small gap of the RPS value among different vaccine types might be mainly due to the difference of the amount of uptaken antigen, stimulus intensities and vaccination site. On another hand, oral vaccination offers the advantage of being easy to administer a large number of fish at one time, and it is less likely to cause immunological stress and mortality during vaccination [39]. More importantly, LAB as a functional feed additive may significantly increase weight gains and feed efficiencies [22].

Being the first barrier against the pathogens infections, mucosal immune system plays a critical role in pathogenic defense and induction of immunity. Many studies showed that oral live vector vaccine could simultaneously trigger the mucosal immune and systemic immune response of vaccinated animals [40-42]. A similar phenomenon was observed in this work: the specific IgM antibody against HIRRV were both detected in serum and gut mucus of flounders orally vaccinated with Ll:pSLC-G. Interestingly, the significant increase of antibody level was detected earlier in mucus, which indicated that mucosal immune response was quickly evoked and produced mucosal antibodies post oral vaccination. The similar result was also found in immersion vaccination in our previous work [43]. Taken together, oral vaccine can effectively trigger the mucosal and systemic immune responses, whereas mucosal immunity seems to make a quicker response.

The colonization experiment of probiotics in animals showed that colonizing bacteria can persist for different time durations in gut. In mouse model, several studies showed that $\mathrm{LAB}$ could exist in gut for a few days $[44,45]$, while some discovered that some of LAB species could not colonize the digestive tracts of man and animals, but can survive passage through the gut [28, 46]. In rainbow trout, approximately half proportions of lactobacillus were detected in the intestine at day 7 compared to the first day [40]. In the present work, we found that a portion of L. lactis NZ9000 has the ability to survive and adhere to the intestine in flounder and can last for at least 3 weeks. It is probably that the difference of colonizing duration may be associated with characteristics of bacteria, quantity of external supplement and the existing gastrointestinal microbiota. In addition, considerable colonization could also be achieved by continuous feeding with a high dose of probiotic bacteria for a period of time $[47,48]$. Therefore, 

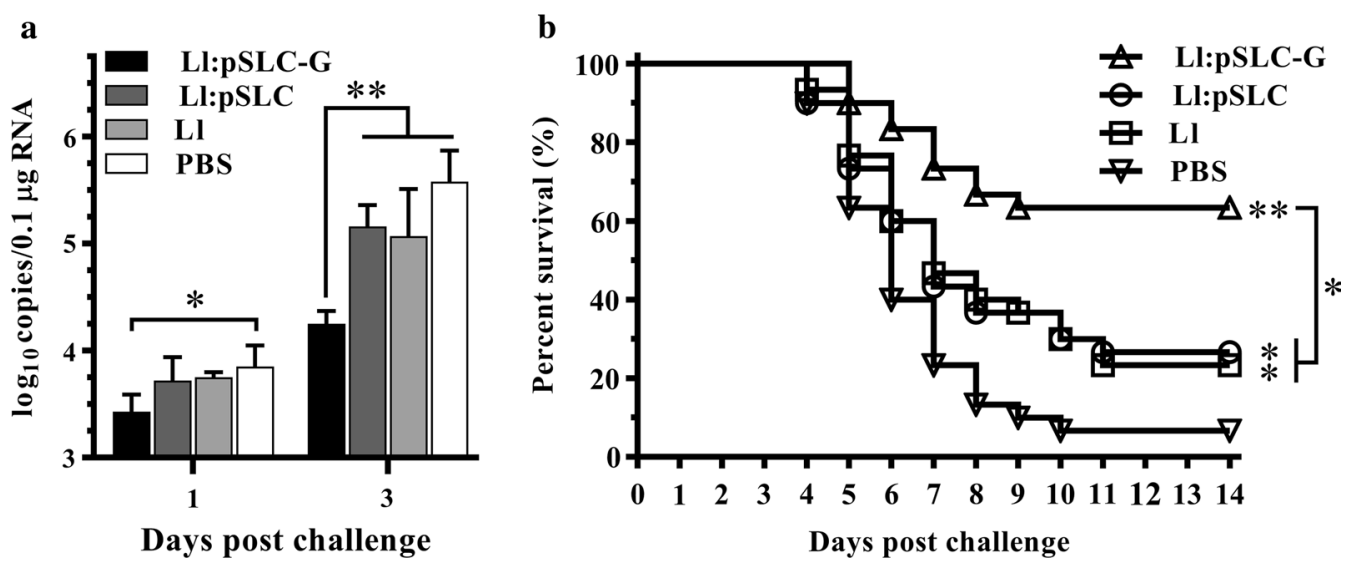

Fig. 6 Immunoprotective effects against HIRRV elicited by oral vaccine. a Virus loads in spleens of vaccinated flounders post-challenge with HIRRV. Mean viral loads and standard deviation were represented in $\log _{10}$ scale. $\mathbf{b}$ The survival rates of flounder in each group, $n=30$. Statistical significance was calculated after comparing PBS group by the Log-rank (Mantel-Cox) method. ${ }^{*}$ indicates $p<0.05,{ }^{* *}$ indicates $p<0.01$

continuous or intermittent enhanced inoculation is necessary for strong and persistent immunity.

Antigen dose and vaccination scheme are crucial issues for each vaccine system [28], and have a considerable impact on immune response of vaccinated host. Our previous studies have demonstrated that the immune response is correlated to the antigen dose in injection vaccination and immersion vaccination [43, 49]. In oral vaccination, researches showed that a booster vaccination could induce a higher level of immune response in flounder and common carp [23, 41]. Therefore, a booster vaccination was conducted in this work, and the result showed that higher levels of specific IgM were produced compared to the primary immunization, indicating a prime-boost strategy is required for this oral vaccine inoculation. In order to achieve better efficacy, the immune dosage and feeding scheme need to be further optimized and explored.

\section{Conclusions}

A surface-displayed system of $L$. lactis was constructed and the G protein of HIRRV was successfully expressed. Flounders fed with recombinant Lactococcus expressing $\mathrm{G}$ protein were triggered mucosal and systemic immune response, and exhibited a considerable protective effect against HIRRV. Hence, the genetically engineered $L$. lactis expressing $\mathrm{G}$ protein can be employed as a promising oral vaccine for flounder against HIRRV infection.

\section{Methods}

\section{Bacterial strains, virus and fish}

Bacterial strains and plasmids used in this study are listed in Additional file 1: Table S1. E. coli strains were grown in Luria-Bertani broth at $37^{\circ} \mathrm{C}$ with vigorous shaking, while
L. lactis strains were grown in GM17 (M17 medium supplemented with $0.5 \%$ glucose) broth at $30{ }^{\circ} \mathrm{C}$ without agitation. Agar (1.5\%) was added to the medium for the plates. When necessary, ampicillin $(100 \mu \mathrm{g} / \mathrm{ml})$, kanamycin $(50 \mu \mathrm{g} / \mathrm{ml})$ and chloramphenicol $(10 \mu \mathrm{g} / \mathrm{ml})$ were used for E. coli, and chloramphenicol $(10 \mu \mathrm{g} / \mathrm{ml})$ and nisin $(50 \mathrm{ng} / \mathrm{ml})$ were used for $L$. lactis.

The HIRRV CNPo2015 strain, isolated from cultured flounder in 2015 [50], was used in this study. The virus was propagated in epithelioma papulosum cyprini (EPC) cell cultures at $15{ }^{\circ} \mathrm{C}$, supplemented with $4 \%$ (v/v) fetal bovine serum (FBS), $100 \mathrm{IU} / \mathrm{ml}$ penicillin G, and $100 \mathrm{mg} /$ $\mathrm{ml}$ streptomycin (Gibco, USA). When virus titer was around $1 \times 10^{6.8} \mathrm{TCID}_{50} / 100 \mu \mathrm{l}$, the cell cultures were harvested and centrifuged to remove cell debris. The supernatant was collected as virus supernatant for the following ELISA and challenge assay.

Specific pathogen-free flounders with body weights of $35 \pm 5 \mathrm{~g}$ were obtained from an aquafarm in Rizhao, Shandong province of China. Before vaccination, the fish were maintained at $18-20^{\circ} \mathrm{C}$ in tanks containing aerated sand-filtered seawater and fed daily with commercial diet (Great Seven, Qingdao, China) for 1 week.

\section{Antibodies preparation}

HIRRV-G gene excluding the region of signal peptide was amplified from the virus genome with the primers G-F/G-R (Additional file 1: Table S1); the product was cloned into pET-28a vector and transformed into E. coli Transetta (DE3) (Transgen, Beijing, China). Following nucleotide sequencing, the confirmed clone was cultured in LB broth and induced by adding $1 \mathrm{mM}$ isopropylthiogalactoside. Eight hours growth later, the cells were collected, sonicated and purified using His $\operatorname{Trap}^{\mathrm{TM}} \mathrm{HP}$ 
Ni-Agarose (GE healthcare, Beijing, China) [51]. After dialysis, the protein purity was checked by SDS-PAGE and the concentration was quantified by BCA protein assay kit (Sangon Biotech, Shanghai, China). The recombinant glycoprotein was used to immunize Balb/c mice to produce the mouse anti-rG polyclonal antibodies according to the previous immunization procedure [52]. After immunization, antiserum was obtained from immunized mice, purified with protein G-agarose column (Pierce/ Thermo Scientific) and characterized by western blotting.

Rabbit anti-L. lactis NZ9000 Pab was also prepared in this study. After cultivation, L. lactis cells were harvested and inactivated with PBS containing $0.5 \%$ formalin $(\mathrm{v} / \mathrm{v})$ for $72 \mathrm{~h}$ at $30{ }^{\circ} \mathrm{C}$. Following reconfirmation by plate culture, inactivated L. lactis NZ9000 cells were washed with sterilized PBS, and the concentration was adjusted to $1.0 \times 10^{10} \mathrm{cfu} \mathrm{ml}^{-1}$. New Zealand white rabbit was immunized with inactivated L. lactis four times, and the polyclonal antiserum was taken when the titer reached to 1:100,000-200,000. After purification, the concentration and purity of the IgG fraction were estimated using BCA protein assay kit and SDS-PAGE, respectively.

Mouse anti-flounder IgM monoclonal antibody (FIgMMab) was produced previously in our laboratory [52], and the dilution used in ELISA was 1: 1000.

\section{Construction of bacterial expression cassette}

pET-32a, an expression vector for $E$. coli, was utilized for assembly of the cloning fragments. pNZ8148, an E. coli$L$. lactis shuttle vector, was used as the $L$. lactis expression vector after subcloning of entire cassettes.

The signal peptide of Usp45 and the C-terminal anchor domain of AcmA gene fragments were amplified from L. lactis MG1363 genomic DNA using two primer pairs $\mathrm{SP}_{\mathrm{Usp} 45}-\mathrm{F} / \mathrm{SP}_{\mathrm{Usp} 45}-\mathrm{R}$ and $\mathrm{cA}-\mathrm{F} / \mathrm{cA}-\mathrm{R}$ (Additional file 1: Table S1), respectively. The purified products were digested with restriction enzymes $\mathrm{NcoI} / \mathrm{BamHI}\left(\mathrm{SP}_{\mathrm{Usp} 45}\right)$ and BamHI/HindIII (cA), respectively, and ligated into the pET-32a vector one by one using T4 DNA ligase to be joined together. It is noted that the LEISSTCDA nucleotide sequence has been incorporated into the reverse primer of Usp45, which has been reported to increase the secretion of the heterologous proteins in L. lactis [32]. Besides, MCS sequences containing five restriction enzyme genes (SacI, SalI, EcoRI and HindIII in order of ORF) were integrated into the reverse primer of cA. The fused fragment containing $\mathrm{SP}_{\mathrm{usp} 45}$ and cA domain in pET32a vector was named as SLC and is flanked by restriction enzymes NcoI and HindIII. Next, the connected fragment SLC was cleaved with $\mathrm{NcoI} / \mathrm{HindIII}$ restriction enzymes and cloned into the same sites on pNZ8148 under the promoter of nisA, generating an expression cassette named pSLC. The recombinant vector was transformed into E. coli MC1061 competent cells, which were prepared by treatment with $0.1 \mathrm{M}$ of cooled $\mathrm{CaCl}_{2}$ [53].

The amplified $\mathrm{G}$ gene mentioned above was inserted after cA domains in pSLC by digestion with restriction enzymes SacI and HindIII, yielding pSLC-G (Fig. 1b). The DNA sequence of G gene in PSLC-G vector was confirmed via nucleotide sequencing by Tsingke Bio (Qingdao, China).

\section{Transformation of $L$. lactis cells and induction expression}

The recombinant plasmids were transformed into $L$. lactis NZ9000 by electroporation as previously described [54] with certain modifications. For competent cell preparation, an overnight culture of L. lactis NZ9000 was inoculated 1:50 in fresh GM17 broth containing 1\% glycine and $0.5 \mathrm{M}$ sucrose and incubated at $30{ }^{\circ} \mathrm{C}$. At early exponential phase $\left(\mathrm{OD}_{600}=0.5\right)$, the culture was harvested by centrifugation $\left(5000 \mathrm{~g}, 4{ }^{\circ} \mathrm{C}\right.$ and $\left.10 \mathrm{~min}\right)$. The pellet was washed thrice with an ice-cold washing

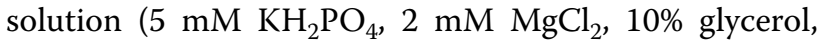
$0.5 \mathrm{M}$ sucrose), resuspended in $1 / 100$ culture volume of washing solution and then electroporated immediately or stored in aliquots at $-80{ }^{\circ} \mathrm{C}$. For electroporation, 40 $\mu \mathrm{l}$ of prepared competent cell was mixed with $1 \mu \mathrm{g}$ of recombinant plasmid dissolved in double-distilled water, and transferred to an ice-cooled electroporation cuvette $(0.2 \mathrm{~mm})$. A single pulse was delivered by a Gene Pulser (Bio-Rad, USA) at $2.0 \mathrm{kV}, 200 \Omega$ for $4.0 \mathrm{~ms}$. Immediately, the cell suspension was mixed with $900 \mu$ l of recovery medium (GM17 broth containing $0.5 \mathrm{M}$ sucrose, $20 \mathrm{mM}$ $\mathrm{MgCl}_{2}$ and $2 \mathrm{mM} \mathrm{CaCl}_{2}$ ) and incubated at $30{ }^{\circ} \mathrm{C}$ for $2 \mathrm{~h}$. After that, $200 \mu \mathrm{l}$ of suspension culture was spread on GM17 plate containing chloramphenicol and incubated for 2 days. Two constructed Lactococcus lactis were denoted Ll:pSLC and Ll:pSLC-G, respectively.

For induction, recombinant $L$. lactis cells were cultured overnight in GM17 broth with chloramphenicol and then inoculated 1:50 in fresh GM17 medium. When the $\mathrm{OD}_{600}$ of the culture reached 0.6 , nisin was added and cultured for an additional $3 \mathrm{~h}$. Then, the bacterial cells were collected by centrifugation $\left(8000 \mathrm{~g}, 4{ }^{\circ} \mathrm{C}\right.$ and $5 \mathrm{~min}$ ) for the following assays.

\section{Western blotting and mass spectrometry analysis}

After centrifugation of the induced bacterial culture, the supernatant and cells were processed separately $[55,56]$. The supernatant was filtered through $0.2-\mu \mathrm{m}$-size filter and proteins were precipitated by adding ice-cold $80 \%$ (w/v) TCA (16\% final concentration). After washing twice with precooled acetone, the resulting pellet was dried in a vacuum centrifuge and dissolved in $50 \mathrm{mM} \mathrm{NaOH}$. On the other hand, the cell pellets were washed twice with 
TES buffer (50 mM Tris-HCl, 1 mM EDTA, 25\% sucrose; $\mathrm{pH} 8$ ), resuspended in $10 \%$ volume cultures of TES buffer containing lysozyme $(1 \mathrm{mg} / \mathrm{ml})$ and subsequently incubated at $37{ }^{\circ} \mathrm{C}$ for $30 \mathrm{~min}$. Then, the cell lysates were treated with ultrasound generator (Sonics VC750, USA; $750 \mathrm{~W}, 20 \mathrm{kHZ}$ ) on ice for $15 \mathrm{~min}$ (on and off cycle of $5 \mathrm{~s}$ at $36 \%$ amplitude). Finally, all samples were added with equal volumes of $2 \times$ loading buffer and subjected to SDS-PAGE (10\% polyacrylamide). One was stained with Coomassie brilliant bule R-250, and others were transferred to polyvinyldifluoride (PVDF) membrane (Merck Millipore, USA). The PVDF membrane was blocked overnight with $4 \%$ bovine serum albumin (BSA) in PBS at $4{ }^{\circ} \mathrm{C}$. Mouse anti-rG Pab and alkaline phosphatase (AP)-conjugated goat anti-mouse IgG (1:3000, Merck Millipore) were used as primary and secondary antibodies, respectively. Finally, the bands were stained with fresh substrate solution $(100 \mathrm{mM} \mathrm{NaCl}, 100 \mathrm{mM}$ Tris and $5 \mathrm{mM} \mathrm{MgCl} 2$; $\mathrm{pH}$ 9.5) containing nitroblue tetrazolium and 5-bromo-4-chloro-3-indolyl phosphate substrates (NBT/BCIP, Sigma), and the reaction was stopped by washing with distilled water.

According to the positive band in the PVDF membrane, the relevant band in polyacrylamide gels was excised, reduced and alkylated by $10 \mathrm{mM}$ dithiothreitol and $55 \mathrm{mM}$ iodoacetamide for protein identification using MS by Shanghai Applied Protein Technology (Shanghai, China).

\section{Immunofluorescence and FCM assays}

For confirmation of the surface-displayed expression of recombinant Lactococcus lactis, IFA was performed as described [57]. The induced cultures of bacteria were harvested and washed twice with PBS. Cell pellets were suspended in sterile PBS containing 4\% BSA and mouse anti-rG Pab, and incubated for $2 \mathrm{~h}$ at $37{ }^{\circ} \mathrm{C}$. Goat antimouse IgG-488 conjugate (Dylight, Abbkine, China) was used as secondary antibody at a dilution of 1:500. After that, cells were washed three times with PBS. A drop of the suspension was laid onto APES coated slides and observed with fluorescence microscope. In parallel, the cell suspensions were diluted to approximately $10^{6}$ cells $/ \mathrm{ml}$ and analyzed by Accuri C6 flow cytometer (BD, Accuuri $^{\mathrm{TM}}$, Piscataway, NJ, USA). The primary antibody replaced with mouse negative serum was used as negative control.

\section{Vaccination and sampling of flounder}

For oral vaccination, the induced cultures of recombinant L. lactis were mixed evenly with commercial diet at the final concentration of $1.0 \times 10^{9} \mathrm{cfu} / \mathrm{g}$ diet. After air drying, the LAB-based feed pellets were enwrapped with sodium alginate $(0.6 \%, w / w$; food grade) and fish oil ( $1 \%$, $v / w$ ) onto their surface and kept at $4{ }^{\circ} \mathrm{C}$ prior to feeding. Four groups were divided with 150 fish in each one. Experimental group of fish was fed with baits containing Ll:pSLC-G, while control group were fed with baits containing Ll:pSLC, Ll or PBS, respectively. Oral vaccination was performed at week 1 (first vaccination) and week 5 (booster vaccination) with a feeding rate of $1-2 \%$ body weight daily. Beyond those, the fish were fed regular pellet feed.

For the detection of specific antibodies, five fish from each group were randomly sacrificed to collect blood and gut mucus at weeks $0,2,4,6,8$ since the beginning of feeding. Serum were separated from blood via overnight standing at $4{ }^{\circ} \mathrm{C}$ and centrifugation and then stored at $-80{ }^{\circ} \mathrm{C}$ until usage. Gut mucus was collected according to the method in previous studies [58,59]. Briefly, gut mucus samples were collected by gently scraping the inner surface of hindgut with PBS containing $1 \mathrm{mM}$ phenylmethylsulfonyl fluoride and $0.5 \%$ BSA. After vortexing and centrifugation, the supernatants were concentrated about tenfold with the same volume in all samples and stored at $-80^{\circ} \mathrm{C}$ until usage.

\section{Adhesion study}

To detect the colonization and proportion of recombinant L. lactis NZ9000 in fish intestine tract after one week of oral feeding, five fish in Ll:pSLC-G group and PBS group (negative control) were sacrificed on days $1,7,14$ and 21 post feeding. Fish were starved for $24 \mathrm{~h}$ prior to collection and the sampling procedure was as follows. Firstly, scrub the ventral surface with $75 \%$ ethanol, extract the intestine and separate it into foregut, midgut and hindgut. Remove visible residual food particles, transfer the sections to sterile dishes and weigh. Then, wash twice with sterile PBS to rinse the passage bacteria, homogenize them and serially dilute in sterile PBS. After that, $150 \mu \mathrm{l}$ of each sample was spread on GM17 agar plates with chloramphenicol and incubated at $30{ }^{\circ} \mathrm{C}$ for $1-2$ days. When typical bacterial characteristics occurred, the bacterial colonies were counted and determined as $\log _{10} \mathrm{cfu} / \mathrm{g}$ tissues. Furthermore, 10 single colonies from each sample were randomly selected and subjected to colony PCR with the primers pNZ-F/pNZ-R and nisRK-F/nisRK-R (Additional file 1: Table S1), which were used to identify L. lactis NZ9000 and the expression cassette of recombinant plasmid, respectively. PCR products were confirmed by nucleotide sequencing.

On the other hand, the intestine samples on the third day post oral feeding were prepared for tissue cryosections according to previous description [59], and IFA was carried out. Briefly, after blocking, sections were incubated with rabbit anti-L. lactis NZ9000 Pab (1:2000) and mouse anti-rG Pab (1:800) for $1.5 \mathrm{~h}$ at $37^{\circ} \mathrm{C}$. 
Non-immune mouse and rabbit serum were used as negative control. After washing, goat anti-rabbit IgG-Cy3 conjugate (1:400, Merck Millipore) and goat anti-mouse IgG-488 conjugate (1:500, Dylight) were incubated for $1 \mathrm{~h}$ as secondary antibodies. After that, the sections were stained with DAPI for $10 \mathrm{~min}$ at room temperature and observed with fluorescence microscopy. All incubations were conducted in a moisture chamber in the dark, followed by three washes with PBST.

\section{Detection of antibodies against HIRRV by ELISA}

To detect the specific IgM against HIRRV in serum and gut mucus, $100 \mu \mathrm{l}$ of prepared virus supernatant was coated into wells of microplates (96-wells, Costar) overnight at $4{ }^{\circ} \mathrm{C}$. After three washes with PBST (PBS containing $0.05 \%$ Tween-20), all wells were blocked with $4 \%$ BSA at $37{ }^{\circ} \mathrm{C}$ for $2 \mathrm{~h}$. Thereafter, serum or mucus samples (1:20 diluted in PBS) from five flounder were incubated for $1.5 \mathrm{~h}$ as primary antibodies. FIgM-Mab and alkaline phosphatase-conjugated goat anti-mouse IgG were sequentially added into each well and incubated for $1 \mathrm{~h}$ as the secondary and third antibodies, respectively. Following three washes, $100 \mu \mathrm{l} 0.1 \%(w / v)$ p-nitrophenyl phosphate (pNPP, Sigma, USA) in $50 \mathrm{mM}$ carbonatebicarbonate buffer ( $\mathrm{pH} 9.8$ ) containing $0.5 \mathrm{mM} \mathrm{MgCl}_{2}$ was added to each well and incubated at room temperature for $20 \mathrm{~min}$ in the dark. The reaction was stopped with $50 \mu \mathrm{l}$ per well of $2 \mathrm{M} \mathrm{NaOH}$ and absorbance was measured with an automatic ELISA reader at $405 \mathrm{~nm}$. Myeloma culture supernatant instead of FIgM-Mab was used as the negative control, and each sample was accessed in three parallels.

\section{Challenge and sample collection}

After the last sampling at 8th week, all fish were transferred to tanks equipped with a refrigerating apparatus and adapted to $14{ }^{\circ} \mathrm{C}$ by gradual decrease of water temperature. One week later, all the fish of four experimental groups were intraperitoneally injected with $100 \mu \mathrm{l}$ of prepared virus suspension ( $10^{6.8} \mathrm{TCID} 50 /$ fish) according to the lethal dose (LD50) in flounder [50]. After challenge, thirty fish were randomly selected from each experimental group for monitoring mortality. Mortality was recorded daily for $14 \mathrm{~d}$ post-challenge and RPS was calculated using the following formula: $(1-\%$ mortality of vaccinated fish $/ \%$ mortality of control fish $) \times 100$. Another thirty fish were randomly selected from each experimental group for monitoring the HIRRV proliferation in the spleen of infected flounder. For sampling, three fish from each group were sacrificed on day 1 and day 3 post-injection, and the spleens were sampled and stored in Sample Protector (Takara) at $-80^{\circ} \mathrm{C}$ until usage.

\section{Detection of HIRRV load by quantitative PCR}

The absolute fluorescence quantitative PCR standard curve has been established for quantifying the $G$ gene copies [60]. The fragment of HIRRV-G gene was cloned into the pMD19-T vector with the primers $\mathrm{G}-\mathrm{qF}$ and G-qR (Additional file 1: Table S1) to construct standard plasmid. After purification and quantification, the copy number was calculated as described previously [61], and it was diluted in tenfold serial dilution series as templates for qPCR assay using Roche 480 real-time PCR system (LightCycler ${ }^{\circledR} 480$, USA). The $20 \mu$ l volume of the reaction mixture containing $10 \mu \mathrm{l}$ of SYBR Green I Master, $1 \mu \mathrm{l}$ of forward and reverse primers $(10 \mu \mathrm{M})$, $1 \mu \mathrm{l}$ of each diluted standard plasmid and $7 \mu \mathrm{l}$ of RNasefree water, was subjected to the following procedure: $95{ }^{\circ} \mathrm{C}$ for $10 \mathrm{~min}$, followed by 40 cycles at $95^{\circ} \mathrm{C}$ for $30 \mathrm{~s}$ and $60{ }^{\circ} \mathrm{C}$ for $1 \mathrm{~min}$. Thereafter, the threshold cycle $(\mathrm{Ct})$ values were measured and standard curve equations $\left(y=-3.6984 x+41.964, R^{2}=0.9996\right)$ were produced by regression analysis of mean $\mathrm{Ct}(\mathrm{y})$ versus the log of standard plasmid copy numbers $(\mathrm{x})$.

$1 \mu \mathrm{g}$ of total RNA from spleen samples was reverse transcribed into cDNA and then $2 \mu \mathrm{l}$ of the products was used as the templates for qPCR. Following the manual above, the assay was performed in triplicate for each sample and non-infected samples were used as the negative control. After amplification, viral copies were determined by extrapolating $\mathrm{Ct}$ values from the standard curve and expressed as mean $\log _{10}$ copies/0.1 $\mu \mathrm{g}$ RNA.

\section{Statistical analysis}

The comparison of antibodies production and viral copies were performed with one-way analysis of variance (ANOVA) using SPSS 20.0 software; the results were expressed as mean $\pm \mathrm{SD}$ and the significance level was defined as $p<0.05$. The survival rates following HIRRV challenge were compared by Log-rank (Mantel-Cox) test using GraphPad Prism 7 software.

\section{Supplementary information}

Supplementary information accompanies this paper at https://doi. org/10.1186/s12934-019-1195-9.

Additional file 1: Table S1. Bacterial strains, plasmids and primers used in this study. Figure $\mathbf{S} 1$. Mass spectrographic analysis of the $\mathrm{G}$ protein expressed by L. lactis NZ9000. (A) The amino acid sequence of HIRRV-G protein. Eight matched peptides were underlined and two of the best matched peptides were labeled in bold. (B) Fingerprints of the two best matched peptides. (C) The matched protein information of mass spectrometric analysis.

\section{Acknowledgements}

Not applicable. 


\section{Authors' contributions}

WZ conceived and designed the study. XT designed the experiments. LZ performed the experiments. XS and JX provided critique to the manuscript. LZ and XT contributed to data analysis and manuscript preparation. All authors read and approved the final manuscript.

\section{Funding}

This study was supported by the National Natural Science Foundation of China $(31730101 ; 31872590 ; 31672685 ; 31672684 ; 31472295)$, Natural Science Foundation of Shandong Province (ZR2019MC029), National key Research and Development Program of China (2018YFD0900503), Fundamental Research Funds for the Central Universities (201822015) and Taishan Scholar Program of Shandong Province.

\section{Availability of data and materials}

All data generated or analyzed during this study are included in this published article and its additional file.

\section{Ethics approval and consent to participate}

This study was performed in strict accordance with the recommendations in the Guide for the Institutional Animal Care and Use Commission (IACUC). The protocols were approved by the Committee on the Ethics of Animal Experiments of the Ocean University of China (Permit Number: 20150101). All experiments were performed under MS-222 anesthesia, and every effort was made to minimize suffering.

\section{Consent for publication}

Not applicable.

\section{Competing interests}

The authors declare that they have no competing interests.

\begin{abstract}
Author details
${ }^{1}$ Laboratory of Pathology and Immunology of Aquatic Animals, KLMME, Ocean University of China, 5 Yushan Road, Qingdao 266003, China. ${ }^{2}$ Laboratory for Marine Fisheries Science and Food Production Processes, Qingdao National Laboratory for Marine Science and Technology, Qingdao 266071, China.
\end{abstract}

Received: 26 June 2019 Accepted: 14 August 2019 Published online: 21 August 2019

\section{References}

1. Kimura T, Yoshimizu M, Gorie S. A new rhabdovirus isolated in Japan from cultured hirame (Japanese flounder) Paralichthys olivaceus and ayu Plecoglossus altivelis. Dis Aquat Organ. 1986;1(3):209-17.

2. Sun YJ, Jiang YL, Liu H, Gao LY, Shi XJ, He JQ, Wang Z. The isolation and characterization of a rhabdovirus from stone flounder, Kareius bicoloratus. Chin J Vet Sci. 2009;29(3):277-82.

3. Kim WS, Oh MJ. Hirame rhabdovirus (HIRRV) as the cause of a natural disease outbreak in cultured black seabream (Acanthopagrus schlegeli) in Korea. Arch Virol. 2015;160(12):3063-6.

4. Seo HG, Do JW, Jung SH, Han HJ. Outbreak of hirame rhabdovirus infection in cultured spotted sea bass Lateolabrax maculatus on the western coast of Korea. J Fish Dis. 2016;39(10):1239-46.

5. Borzym E, Matras M, Maj-Paluch J, Baud M, De Boisseson C, Talbi C, Olesen $\mathrm{NJ}$, Bigarre L. First isolation of hirame rhabdovirus from freshwater fish in Europe. J Fish Dis. 2014;37(5):423-30.

6. Gudding R, Van Muiswinkel WB. A history of fish vaccination: sciencebased disease prevention in aquaculture. Fish Shellfish Immunol. 2013;35(6):1683-8.

7. Björklund $\mathrm{HV}$, Higman $\mathrm{KH}$, Kurath $\mathrm{G}$. The glycoprotein genes and gene junctions of the fish rhabdoviruses spring viremia of carp virus and hirame rhabdovirus: analysis of relationships with other rhabdoviruses. Virus Res. 1996;42(1-2):65-80.

8. Hill BJ. Physico-chemical and serological characterization of five rhabdoviruses infecting fish. J Gen Virol. 1975;27(3):369.
9. Jounglm EOU, MyungJoo OH, SungJu J, YoungHwan S, TaeJin C. The protective effect of recombinant glycoprotein vaccine against HIRRV infection. Fish Pathol. 2001;36(2):67-72

10. Takano T, Iwahori A, Hirono I, Aoki T. Development of a DNA vaccine against hirame rhabdovirus and analysis of the expression of immune-related genes after vaccination. Fish Shellfish Immunol. 2004;17(4):367-74.

11. Seo JY, Kim KH, Kim SG, Oh MJ, Nam SW, Kim YT, Choi TJ. Protection of flounder against hirame rhabdovirus (HIRRV) with a DNA vaccine containing the glycoprotein gene. Vaccine. 2006;24(7):1009-15.

12. Kim MS, Kim KH. Generation of recombinant viral hemorrhagic septicemia viruses (VHSVs) harboring G gene of hirame rhabdovirus (HIRRV) and their ability to induce serum neutralization activity in olive flounder (Paralichthys olivaceus). Aquaculture. 2012;330-333:37-41.

13. Plant KP, Lapatra SE. Advances in fish vaccine delivery. Dev Comp Immunol. 2011;35(12):1256-62.

14. Chen HM. Recent advances in mucosal vaccine development. J Control Release. 2000;67(2-3):117-28.

15. Wells JM, Mercenier A. Mucosal delivery of therapeutic and prophylactic molecules using lactic acid bacteria. Nat Rev Microbiol. 2008;6(5):349-62

16. Song $A A L$, In LLA, Lim SHE, Rahim RA. A review on Lactococcus lactis: from food to factory. Microb Cell Fact. 2017;16(1):55.

17. Bermúdez-Humarán LG, Aubry C, Motta JP, Deraison C, Steidler L, Vergnolle N, Chatel JM, Langella P. Engineering lactococci and lactobacilli for human health. Curr Opin Microbiol. 2013;16(3):278-83.

18. Ma DX, Gao MY, Dalloul RA, Ge JW, Ma CL, Li J. Protective effects of oral immunization with live Lactococcus lactis expressing Eimeria tenella 3-1E protein. Parasitol Res. 2013;112(12):4161-7.

19. Asensi GF, de Sales NFF, Dutra FF, Feijó DF, Bozza MT, Ulrich RG, Miyoshi A, De Morais K, de Carvalho Azevedo VA, Silva JT. Oral immunization with Lactococcus lactis secreting attenuated recombinant staphylococcal enterotoxin $B$ induces a protective immune response in a murine model. Microb Cell Fact. 2013;12(1):32.

20. Bermúdez-Humarán LG, Kharrat P, Chatel J-M, Langella P. Lactococci and lactobacilli as mucosal delivery vectors for therapeutic proteins and DNA vaccines. Microb Cell Fact. 2011;10(Suppl 1):S4.

21. Zhao LL, Liu M, Ge JW, Qiao XY, Li YJ, Liu DQ. Expression of infectious pancreatic necrosis virus (IPNV) VP2-VP3 fusion protein in Lactobacillus casei and immunogenicity in rainbow trouts. Vaccine. 2012;30(10):1823-9.

22. Kim D, Beck BR, Heo SB, Kim J, Kim HD, Lee SM, Kim Y, Oh SY, Lee K, $\mathrm{Do} H$, et al. Lactococcus lactis BFE920 activates the innate immune system of olive flounder (Paralichthys olivaceus), resulting in protection against Streptococcus iniae infection and enhancing feed efficiency and weight gain in large-scale field studies. Fish Shellfish Immunol. 2013;35(5):1585-90.

23. Beck BR, Lee SH, Kim D, Park JH, Lee HK, Kwon S-S, Lee KH, Lee Jl, Song SK. A Lactococcus lactis BFE920 feed vaccine expressing a fusion protein composed of the OmpA and FlgD antigens from Edwardsiella tarda was significantly better at protecting olive flounder (Paralichthys olivaceus) from edwardsiellosis than single antigen vaccines. Fish Shellfish Immunol. 2017:68:19-28

24. Zhang DX, Kang YH, Chen L, Siddiqui SA, Wang CF, Qian AD, Shan XF. Oral immunization with recombinant Lactobacillus casei expressing OmpAl confers protection against Aeromonas veronii challenge in common carp, Cyprinus carpio. Fish Shellfish Immunol. 2018;72:552-63.

25. Pontes DS, de Azevedo MS, Chatel JM, Langella P, Azevedo V, Miyoshi A. Lactococcus lactis as a live vector: heterologous protein production and DNA delivery systems. Protein Expr Purif. 2011;79(2):165-75.

26. Wang W, Song Y, Liu L, Zhang Y, Wang T, Zhang W, Li K, Qi X, Gao Y, Gao $L$, et al. Neutralizing-antibody-mediated protection of chickens against infectious bursal disease via one-time vaccination with inactivated recombinant Lactococcus lactis expressing a fusion protein constructed from the RCK protein of Salmonella enterica and VP2 of infectious bursal disease virus. Microb Cell Fact. 2019;18(1):21.

27. Azizpour M, Hosseini SD, Jafari P, Akbary N. Lactococcus lactis: a new strategy for vaccination. Avicenna J Med Biotechnol. 2017;9(4):163-8.

28. Szatraj K, Szczepankowska AK, Chmielewska-Jeznach M. Lactic acid bacteria-promising vaccine vectors: possibilities, limitations, doubts. J Appl Microbiol. 2017:123(2):325-39. 
29. Mierau I, Kleerebezem M. 10 years of the nisin-controlled gene expression system (NICE) in Lactococcus lactis. Appl Microbiol Biotechnol. 2005;68(6):705-17.

30. Belkis M, Ana Rosa P, Claudia B, Diego DM, Christian M. Oral immunization with live Lactococcus lactis expressing rotavirus VP8 subunit induces specific immune response in mice. J Virol Methods. 2011;175(1):28-37.

31. Zhang X, Hu S, Du X, Li T, Han L, Kong J. Heterologous expression of carcinoembryonic antigen in Lactococcus lactis via LcsB-mediated surface displaying system for oral vaccine development. J Microbiol Immunol Infect. 2016;49(6):851-8.

32. Loir YL, Gruss A, Ehrlich SD, Langella P. A nine-residue synthetic propeptide enhances secretion efficiency of heterologous proteins in Lactococcus lactis. J Bacteriol. 1998;180(7):1895-903.

33. Okano K, Zhang Q, Kimura S, Narita J, Tanaka T, Fukuda H, Kondo A. System using tandem repeats of the cA peptidoglycan-binding domain from Lactococcus lactis for display of both $\mathrm{N}$ - and C-terminal fusions on cell surfaces of lactic acid bacteria. Appl Environ Microbiol. 2008;74(4):1117-23

34. Lim SH, Jahanshiri F, Rahim RA, Sekawi Z, Yusoff K. Surface display of respiratory syncytial virus glycoproteins in Lactococcus lactis NZ9000. Lett Appl Microbiol. 2010;51(6):658-64.

35. Škrlec K, Zadravec $P$, Hlavničková $M$, Kuchař M, Vaňková L, Petroková H, Kř́žová L, Černý J, Berlec A, Malý P. p19-targeting ILP protein blockers of IL-23/Th-17 pro-inflammatory axis displayed on engineered bacteria of food origin. Int J Mol Sci. 2018;19(7):1933.

36. Ai C, Zhang Q, Ren C, Wang G, Liu X, Tian F, Zhao J, Zhang H, Chen $\mathrm{YQ}$, Chen W. Genetically engineered Lactococcus lactis protect against house dust mite allergy in a BALB/C mouse model. PLOS ONE. 2014;9(10):e109461.

37. Coll JM. The glycoprotein $\mathrm{G}$ of rhabdoviruses. Arch Virol. 1995:140(5):827-51

38. Corbeil S, Lapatra SE, Anderson ED, Jones J, Vincent B, Hsu YL, Kurath $G$. Evaluation of the protective immunogenicity of the N, P, M, NV and $G$ proteins of infectious hematopoietic necrosis virus in rainbow trout Oncorhynchus mykiss using DNA vaccines. Dis Aquat Organ. 1999;39(1):29.

39. Munang'andu H, Paul J, Evensen $\varnothing$. An overview of vaccination strategies and antigen delivery systems for Streptococcus agalactiae vaccines in Nile tilapia (Oreochromis niloticus). Vaccines. 2016:4(4):48.

40. Duan KX, Hua XJ, Wang YT, Wang YX, Chen YX, Shi W, Tang LJ, Li YJ, Liu M. Oral immunization with a recombinant Lactobacillus expressing CK6 fused with VP2 protein against IPNV in rainbow trout (Oncorhynchus mykiss). Fish Shellfish Immunol. 2018:83:223-31.

41. Zhang DX, Kang YH, Chen L, Siddiqui SA, Wang CF, Qian AD, Shan XF. Oral immunization with recombinant Lactobacillus casei expressing OmpAl confers protection against Aeromonas veronii challenge in common carp, Cyprinus carpio. Fish Shellfish Immunol. 2017;72:552-63.

42. Vela Ramirez JE, Sharpe LA, Peppas NA. Current state and challenges in developing oral vaccines. Adv Drug Deliv Rev. 2017;114:116-31.

43. Du $Y$, Tang $X$, Sheng $X$, Xing J, Zhan W. Immune response of flounder (Paralichthys olivaceus) was associated with the concentration of inactivated Edwardsiella tarda and immersion time. Vet Immunol Immunopathol. 2015;167(1-2):44-50.

44. Wang Y, Wang J, Dai W. Use of GFP to trace the colonization of Lactococcus lactis WH-C1 in the gastrointestinal tract of mice. J Microbiol Methods. 2011:86(3):390-2.

45. Li YJ, Ma GP, Li GW, Qiao XY, Ge JW, Tang LJ, Liu M, Liu LW. Oral vaccination with the porcine rotavirus VP4 outer capsid protein expressed by Lactococcus lactis induces specific antibody production. J Biomed Biotechnol. 2010;2010(3):708460.
46. Daniel C, Poiret S, Dennin V Boutillier D, Pot B. Bioluminescence imaging study of spatial and temporal persistence of Lactobacillus plantarum and Lactococcus lactis in living mice. Appl Environ Microbiol. 2013;79(4):1086-94.

47. Bagheri T, Hedayati SA, Yavari V, Alizade M, Farzanfar A. Growth, survival and gut microbial load of rainbow trout (Oncorhynchus mykiss) fry given diet supplemented with probiotic during the two months of first feeding Turk J Fish Aquat Sci. 2008;8(1):43-8.

48. Wang B, Li J, Li Q Z Zhang H, Li N. Isolation of adhesive strains and evaluation of the colonization and immune response by Lactobacillus plantarum L2 in the rat gastrointestinal tract. Int J Food Microbiol. 2009;132(1):59-66.

49. Zeng $C$, Tang $X$, Du Y, Sheng $X$, Xing J, Zhan W. Dynamic distribution of formalin-inactivated Edwardsiella tarda in olive flounder (Paralichthys olivaceus) post intramuscular injection. Vet Immunol Immunopathol. 2018;199:53-60.

50. Zhang J, Tang $X$, Sheng $X$, Xing J, Zhan W. Isolation and identification of a new strain of hirame rhabdovirus (HIRRV) from Japanese flounder Paralichthys olivaceus in China. Virol J. 2017;14(1):73.

51. Zhang Z, Lv Z, Shao Y, Qiu Q, Zhang W, Duan X, Li Y, Li C. Microsomal glutathione transferase 1 attenuated ROS-induced lipid peroxidation in Apostichopus japonicus. Dev Comp Immunol. 2017;73:79-87.

52. Li Q, Zhan W, Xing J, Sheng X. Production, characterisation and applicability of monoclonal antibodies to immunoglobulin of Japanese flounder (Paralichthys olivaceus). Fish Shellfish Immunol. 2007;23(5):982-90.

53. Hanahan D. Studies on transformation of Escherichia coli with plasmids. J Mol Biol. 1983;166(4):557-80.

54. Landete JM, Arques JL, Peiroten A, Langa S, Medina M. An improved method for the electrotransformation of lactic acid bacteria: a comparative survey. J Microbiol Methods. 2014;105:130-3.

55. Dieye Y, Hoekman AJW, Clier F, Juillard V, Boot HJ, Piard JC. Ability of Lactococcus lactis to export viral capsid antigens: a crucial step for development of live vaccines. Appl Environ Microbiol. 2003;69(12):7281-8.

56. Piard J, Hautefort I, Fischetti V, Ehrlich S, Fons M, Gruss A. Cell wall anchoring of the Streptococcus pyogenes M6 protein in various lactic acid bacteria. J Bacteriol. 1997:179(9):3068-72.

57. Kwak YD, Yoo SK, Kim EJ. Cell surface display of human immunodeficiency virus type $1 \mathrm{gp} 120$ on Escherichia coli by using ice nucleation protein. Clin Diagn Lab Immunol. 1999;6(4):499-503.

58. Zhang YA, Salinas I, Li J, Parra D, Bjork S, Xu Z, LaPatra SE, Bartholomew J, Sunyer JO. IgT, a primitive immunoglobulin class specialized in mucosal immunity. Nat Immunol. 2010;11(9):827-35.

59. Sheng $X$, Qian $X$, Tang $X$, Xing J, Zhan W. Polymeric immunoglobulin receptor mediates immune excretion of mucosal IgM-antigen complexes across intestinal epithelium in flounder (Paralichthys olivaceus). Front immunol. 2018;9:1562.

60. Zhang J, Tang $X$, Sheng $X$, Xing J, Zhan W. The influence of temperature on viral replication and antiviral-related genes response in hirame rhabdovirus-infected flounder (Paralichthys olivaceus). Fish Shellfish Immunol. 2017:68:260-5.

61. Fronhoffs S, Totzke G, Stier S, Wernert N, Rothe M, Bruning T, Koch B, Sachinidis A, Vetter H, Ko Y. A method for the rapid construction of CRNA standard curves in quantitative real-time reverse transcription polymerase chain reaction. Mol Cell Probes. 2002;16(2):99-110.

\section{Publisher's Note}

Springer Nature remains neutral with regard to jurisdictional claims in published maps and institutional affiliations. 